\title{
Editorial
}

\section{Can boycotts help save rain forest?}

An ffPS member recently pointed out the contradiction in serving bananas from Ecuador at a Society meeting that included a talk on the threats to rain forests. Extensive tracts of Ecuador's coastal forest have been cleared for banana plantations. Should we then, as he suggested, boycott bananas? If we really care about saving rain forest an unequivocal 'yes' might be the appropriate response. But there are problems with boycotts, as well as points in their favour.

They can be effective, there is no doubt about that. Let us take two recent examples. The US consumer boycott of Norwegian fish, initiated by Greenpeace in protest against Norway's objection to the International Whaling Commission's decision to end commercial whaling by 1986 , has resulted in the loss of several million dollars in contracts with US restaurant chains and direct consumer sales. Frionor, a consortium of more than 100 Norwegian fishing companies, which alone lost at least two contracts worth $\$ 7$ million, has announced that it will cease handling whale meat when the moratorium goes into effect. The International Nestle Boycott Committee and the Infant Formula Action Committee (INFACT) suspended their boycott of the Swiss company's products at the end of 1983 because they had achieved what they had set out to do. The boycott had involved 35 major organisations in 10 countries and was aimed at getting Nestlé to change its infant-food marketing practices in Third World countries because they were endangering the health of infants by encouraging mothers not to breast feed. Now 'Nestle is a model for the whole industry', according to Douglas Johnson of INFACT, but he added that Nestle's competitors, some of whom unfairly exploited the boycott to expand their market share, now will be 'the focus of our attention'. And here are pinpointed two of the problems with boycotts. First, boycotting one company may open a door for another, even less desirable. Secondly, where, on earth, does one stop? In the case of rain forest it is probably impossible to choose a target that reflects conservation priorities. Rubber, sugar, fruits, palm oil, tobacco, beef-all these and many more are raised on land that was once forest. One could probably make a case for sufficient kinds of boycotts almost to empty the supermarket shelves.

To return to the two examples, they owed their effectiveness to large-scale, well-organised operations. Boycotts are only as good as the publicity they engender. And since there seems to be little point in a boycott practised by a few, for it can do little more than salve the consciences of those few, then a boycott aimed at helping to save the rain forests would be costly in time and resources that might be better spent elsewhere.

But a more fundamental problem with boycotts is that they rarely strike at the root of the problem. If we stop eating bananas we could, in theory, lessen demand and save forests. But we should not forget or avoid facing the real threats to the world's forests. As Jack Westoby, who served 22 years with FAO's Department of Forestry, said in an address to the Australian Institute of Foresters last year, the real enemies are those governments that allow the multinationals to operate in destructive ways, without regard to the sustainable use of resources, and those oligarchies where a handful of people hold most of the wealth, land and power so that millions of landless poor are driven to settle and clear the forests. These kinds of governments will not give up their power and privilege easily, especially while they are recognised and thus given tacit approval and support by external powers. Fortunately, within these countries there are also a growing number of people opposed to the destruction of the forests, and conservationists from outside must find ways of acting to encourage these forces. But the devastation of the world's forests is a political problem and political action is what is really necessary. 